\title{
The Casual Effects of Service Quality, Brand Image, Customer Satisfaction on Customer Loyalty in the Leisure Resort Enterprise
}

\author{
Kun-Hsi Liao \\ Taiwan Shoufu University, Tainan, Taiwan
}

\begin{abstract}
Owing to the growth of economic, people have more demand for leisure activities. How to improve customer's loyalty has become a key strategy for service management. The purpose of this study was, taking leisure resort enterprise as an example, to explore the casual relationships between service quality, brand image, customer satisfaction, and customer loyalty. A total of 300 subjects from Taiwan population were voluntarily participated in this study. The LISREL (Linear Structural Relationship) model verification results showed that the overall goodness-of-fit indices (GFI) was 0.952 and $\chi^{2}$ was $128.639(d f=95)$, which indicated an empirically good fit with the model. It was concluded that the service quality, brand image and customer satisfaction of leisure business have a direct relation with loyalty, and the service quality has an indirect effect on loyalty through customer satisfaction. These findings would be a reference for marketing management in the leisure enterprises.
\end{abstract}

Keywords: service quality, brand image, customer satisfaction, customer loyalty, leisure enterprises, LISREL (Linear Structural Relationship)

\section{Introduction}

Leisure enterprise is the segment of service industries, which offers people leisure resort activity. Recent years of flourishing development in the enhancement of national income and for the full implementation of two-day weekend system in Taiwan, people have more time for leisure resort activities. Leisure resort service has become the potential extremely the emergent enterprise. Leisure resort enterprise has also become continued to flourish in the world. As the same time, leisure resort enterprise has also increased competition in the service trades. Systematic view of how to develop business strategies of the leisure enterprise, to strengthen industrial competitiveness is the topic which the entrepreneur needs to take seriously. To remain competitive in the market requires detailed sets of management marketing strategies.

\section{Leisure Service Management}

Induction of a lot of the domestic and foreign related literatures discovered that in the various trades and occupations, the service quality, brand image, customer satisfaction and customer loyalty were related to a greater degree of presence and interaction (Liao, 2007; Liao \& Li, 2011). For example, promoting service

Kun-Hsi Liao, Ph.D., Assistant Professor, Department of Product Development and Design, Taiwan Shoufu University .

Correspondence concerning this article should be addressed to Kun-Hsi Liao, No.168, Nanshi Li, Madou District, Tainan City 72153, Taiwan. E-mail: liaokunh@gmail.com. 
quality, brand image and customer satisfaction are important management strategies that will affect the customer loyalty. Business that can offer high quality service, set up excellent brand image and provide satisfaction to their customers will remain competitive and boast high numbers of customer retention (Parasuraman, Zeithaml, \& Berry, 1996; Grewal, Krishnan, Julie, \& Norm, 1998; Etzel, Walker, \& Stanton, 2001; Jo. Lee, Ja. Lee, \& Feick, 2001). However, in the leisure resort business there are little literature attention has been paid to the service quality, brand image, customer satisfaction and customer loyalty among the four variables relationships. Systematic exploring the casual relationships between service quality, brand image, customer satisfaction and customer loyalty on the leisure resort enterprise is therefore important. The high competition levels in the leisure service trades are focused on customer retention; therefore, constant improvements to service quality, brand image, and customer satisfaction are addressing the issue. When the customer is satisfied, they will continue repurchasing a service. Therefore, to distinguish the relationships among the four variables, service quality, brand image, customer satisfaction, and customer loyalty is very important as it can offer references for enterprises when planning marketing and management strategy.

\section{Aims of Study}

This research used Linear Structural Relationship (LISREL) method to probe the relationships of service quality and brand image to customer satisfaction, then identify their joint influence on consumer's loyalty. The aim of study addresses the following questions:

(1) What are the casual relationships between service quality, brand image, and customer satisfaction and customer loyalty that people experience in the leisure activity in Taiwan?

(2) Hypotheses of this research are as follows:

H1: Service quality is correlated with customer loyalty.

$\mathrm{H} 2$ : Brand image is correlated with customer loyalty.

H3: Customer satisfaction is correlated with customer loyalty.

H4: The casual relationship model among service quality, brand image, customer satisfaction, and customer loyalty is proposed in Figure 1.



Figure 1. Proposed linear structural relationship model.

\section{Review of the Literature}

\section{Overviews of Leisure Enterprise}

Leisure, a multi-billion dollar global enterprise, looks set to make major inroads into the world economy and contribute significantly to the world economy. The leisure enterprise is the segment of business focused on entertainment, recreation, and tourism related products and services (Klaus \& Christine, 2004). In whole world, because of the economic growth with the national income enhancement, the humanity increases day by day to 
the leisure traveling demand, from the sightseeing population, the output value, the disbursement and so on related statistical data can be seen, the leisure enterprise has become the potential extremely the emergent enterprise. For the full implementation of two-day weekend system, people have more time for leisure activities, making the enterprise continued to flourish in Taiwan. The leisure enterprise has become the trend of international trends in important activities.

One of the areas of the economy where there has been a relatively rapid growth of small businesses in recent years is in the sport and leisure enterprise, especially, in leisure resort enterprise (Tim, Thomas, \& Trevor, 1993). How to improve customer satisfaction, in order to effectively master the source, will be the focus on developing business opportunities, but also to compete with other industries, and the key to winning.

\section{Customer Loyalty of Leisure Enterprise}

For all of the competitive business strategies, maintaining customer loyalty is properly the most important factors (Reichheld, 1996). Customer loyalty is the customer continuous purchasing behaviors of the merchandise or services of a certain company (Day, 1977; Griffin, 1996). Reichheld (1996) thought if a customer was satisfied with companies' commodities or services they would want to offer positive word-of-mouth promoting that company. Improving customer loyalty in the service enterprises will increase economic benefits. Therefore, keen competition in service and improved management and marketing strategies must be aimed at retention not acquisition (Dwyer, Schurr, \& Oh, 1987). Regarding evaluation of customer loyalty, Parasuraman, Zeithaml, and Berry (1994) thought that items, which should be included, were behaviors, intent to repurchase, people's recommendations through positive word-of-mouth. There are many factors affecting the customer loyalty, e.g., service of quality, excellent brand image, and overall customer satisfaction (Liao, 2007). Jones and Sasser (1995) sorted customer loyalty to three main categories - customer repurchase intent, primary behavior, and secondary behavior. Griffin (1996) sorted customer loyalty to four main categories - customer repurchase intent, word-of-mouth, participation product activity, and selection of participation product activity. This research adopted four observed variables as indicators to determine the customer loyalty of leisure business in Taiwan (Griffin, 1996; Jones \& Sasser, 1995).

\section{Service Quality in Leisure Services}

Fierce competitive circumstances highlight service quality as the main survival component and competitive weapon in the service enterprise (Parsuraman, Zeithaml, \& Berry, 1985; Reichheld \& Sasser, 1990). Service is the interaction process between a customer and the service provider (Grönroos, 1998). Kenneth, Judith, and David (1995) indicated that cues used by leisure travelers in the evaluation of the more "intangible" purchase criteria were security, dependability, service quality, convenience, and reputation identified. Service quality was one of important criteria factor for repurchase intent. In order to deliver high quality services, leisure facility managers have focused on the expectations of paying customers, to the exclusion of other customer groups. When leisure services are viewed as a whole, quality management appears an appropriate strategy for the management of leisure facilities (Leigh, 2001). Basing on the notion that leisure quality management embraces efficiency and effectiveness. Effectiveness indicators based on the principles of customer service quality measure customers' expectations compared to their perceptions of the centre's actual performance (H. Gary, James, C. Gary, \& Ian, 2001).

Instruments for measuring the quality of services, such as SERVQUAL and its modifications, have been used by several organizations in the service enterprise (Lutz, 1986; George, Eleni, Mario, \& Panagiotis, 2004; 
Bindu, Chandrasekharan, Prakash, \& Ram, 2009). Saravanan and Rao (2007) found that certain important aspects of service quality were not covered in SERVQUAL model. Another instrument SERVPERF is now considered as the best and most correct method for determining service quality (Grönroos, 2003). Bindu et al. (2009) used SERVPERF as an example to study the service quality in tourism. They proposed a conceptual framework and an instrument for measuring the customer-perceived service quality. The perceived service quality of public utility services has a multi-level, multi-dimensional structure with three primary dimensions: outcome, environment and interaction (Changhong, Fujun, Ye, \& Joe, 2008). This research took the SERVPERF method as the norm in order to determine the service quality of the Taiwanese leisure service businesses. Service quality dimensions are tangibles, reliability, responsiveness, assurance, and empathy (Parasuraman et al., 1985; Bindu et al., 2009).

\section{Brand Image Affects Customer's Purchase}

The brand is one kind of name, design, and symbol, or also perhaps the mark of the combination of three. It can be confirmed by entrepreneur's product or the service, in order to distinguish the differences with other competitors (Aaker, 1994). Similarly, brand quality is more valuable for firms facing increasing competition, i.e., unanticipated decreases in industry concentration (Sundar, Kapil, \& Andre, 2011). Chiang and Jang (2007) studied the leisure travelers purchased the hotel intention online. They found that brand image significantly affects quality and trust perceived by consumers. Overall, trust perception appears to play an important role in improving long-term customer value in online dynamics. This study also suggests that if leisure travelers perceive that a price offered by a hotel is more affordable than their internal price standard or competing prices, they tend to believe that quality might be low, but they tend to have high consumer value and are more likely to have greater purchase intention. Hence, brand image may probably be a factor that affects the customer loyalty on the leisure enterprise. Biel (1992) indicated that the brand image had three essential factors, namely, manufacturer image, product image, and competitor brand image. All of the three factors will affect the customer regarding the brand image cognition, but only the brand image will influence the user's image.

\section{Customer Satisfaction, Service Quality, and Customer Loyalty}

The definition of satisfaction refers to a person's approval or disappointment when comparing their personal opinion of services received with their original service expectations (Kotler \& Keller, 2006). Customer satisfaction is a customer's rational and emotional perception, which is based on service experiences (Mackenzie \& Spreng, 1992; Matthew \& Christine, 2000). Martin, Ugur, and Dirk (2003) concluded that consumer satisfaction with leisure services was a function of both cognitive and affective evaluations where the affective evaluations dominate. In a leisure service context, quality and value are proposed as antecedents of satisfaction, with their effects on loyalty mediated by satisfaction (Xiang \& James, 2010). Jennifer and Tom (2007) concluded that Herzberg's theory was capable of expressing service quality dimensions and a better way to address human satisfaction. For leisure service, overall satisfaction has a bearing on visitor's positive word-of-mouth revisit intentions (Antti \& Ugur, 2005). Robert (2001) also showed that tangible elements of the service were thought by customers to be the most important elements. These tangible elements also had the greatest impact on that variation in overall satisfaction. Monica (2009) indicated recognizing the need of more research on the meanings of leisure and tourism in diverse social and cultural contexts. It can be argued that cultural patterns and social structures have greatly influenced the development of Chinese leisure and tourism-how they have been lived, felt, and made sense by Chinese people. Conclusively, customer 
satisfaction may probably be the factor that affects the customer loyalty on the leisure enterprises.

How to determine the customer satisfaction is one of the important roles in this research. Customer satisfaction determination included total satisfaction of service performance as well as the consumer views and national conditions (Singh, 1991; Manfred \& Grund, 2000; Dermanov \& Eklöf, 2001; Chang \& Yuan, 2002). Kuo (2004) used Kano's two-way quality model to categorize web-community service quality dimensions and their elements and understand the demands of users. He found the increase of satisfaction and the decrease of dissatisfaction in the analysis of improvement on certain quality elements, and used the result as a reference for future improvements on services provided to the web-community. David and Dominiek (2008) studied the retirement community resident satisfaction, and finally, they concluded that satisfaction contained five different domains, including the built environment, the financial environment, the service delivery environment, the social environment, and the spiritual environment. Combining the above literatures, this research adopted four aspects to determine customer satisfaction, namely, the personnel service standard, soft hardware equipment, board and lodging, and whole experience feeling (Singh, 1991; Dermanov \& Eklöf, 2001; David \& Dominiek, 2008).

\section{Methodology}

\section{Framework of Research}

According to literature view, this article sets up a structured framework, as shown in Figure 2. This framework expressed the causality relationships among service quality, brand image, customer satisfaction, and customer loyalty. The structural framework explored the relationships of four latent variables and 16 observed variables. The four latent variables were service quality (Sq), brand image (Bi), customer satisfaction (Cs), and customer loyalty $(\mathrm{Cl})$. The 16 observed variables were tangibles (TAN), reliability (REL), responsiveness (RES), assurance (ASS), empathy (EMP), product image (PRI), manufacturer image (MAI), competitor brand image (CBI), personnel service standard (PSS), soft hardware equipment (SHE), board and lodging (BAL), whole experience feeling (WEF), intent to repurchase(ITR), purchase frequency (PUF), recommendation product wish (RPW), and times of participation product activity (TPPA).

The framework supposes that service quality is not only directly influencing customer satisfaction and customer loyalty, but also through customer satisfaction indirectly influencing customer loyalty. Brand image is directly influencing on customer loyalty.

\section{Sample and Data Collection}

The effective numbers of subject for this study in LISREL testing were 300 which were drawn from Taiwan population. Subjects were voluntarily participated in this study. They had been traveled at least one of the following domestic leisure resorts, Nun-Yuan Garden Resort Farm, Tsou-Ma-Lai Leisure Farm, Hu-Tou Pei Scenic Area, Wusanto Reservoir Scenic Area, and Jianshanpi Resort. Data were collected by questionnaire that designed according to a combination of past research studies (Parasuraman, Zeithaml, \& Berry, 1988; Cronin \& Taylor, 1992; Jones \& Sasser, 1995; Chang \& Yuan, 2002). The contents of the questionnaire consisted of five portions, namely, service quality, brand image, customer satisfaction, customer loyalty, and subject information. The central goal of the questionnaire was for understanding the general situation of the overall leisure resort travel experiences that their responses to service quality, brand image, conscientious satisfaction, and customer loyalty. Questionnaire was scored by means of a Likert 5-point scale. The 
questionnaire consisted of 42 items, including, 10 service quality items, eight brand image items, eight customer satisfaction items, six customer loyalty items, and 10 subject information items.

\section{Data Analysis}

Data analysis used SPSS 17.0 and LISREL 8.8 (Jöreskog \& Sörbom, 1998) statistical software to analyze the data. Analyzed contents were categorized into reliability, validity, subject information, correlation, and LISREL model testing. The LISREL structural model is written in the following matrix equation:

$$
\eta=B \eta+\Gamma \xi+\zeta
$$

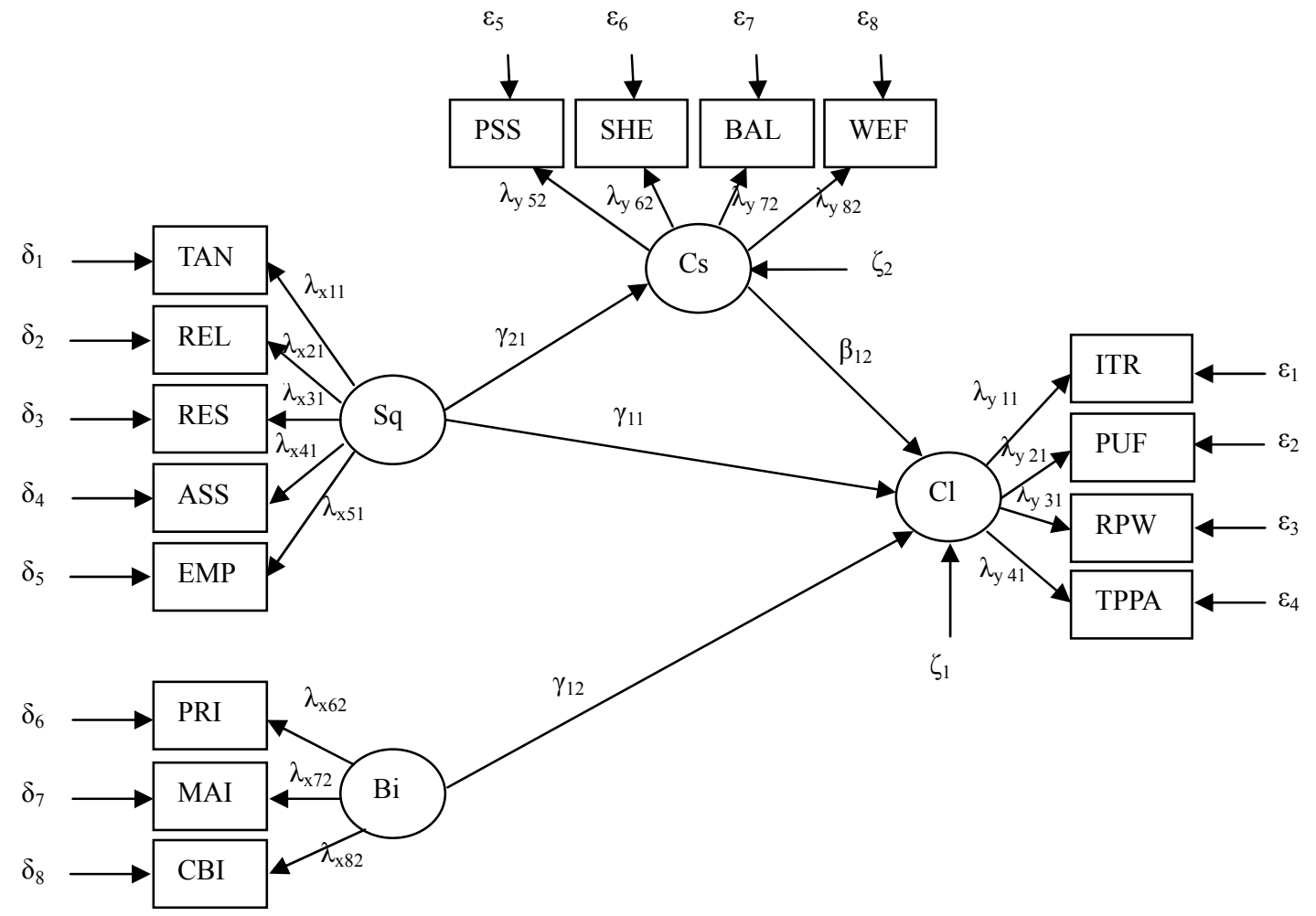

Figure 2. Framework of the linear structural relation model.

The latent dependent variables are denoted by $\eta$ (eta) as a vector $(m \times 1)$ of $m$ such variables. The latent independent variables are denoted by $\xi(\mathrm{xi})$ as a vector $(n \times 1)$ of $n$ such variables. The relationships among the latent variables are denoted by $B$ (capital beta) and $\Gamma$ (capital gamma). The error term $\zeta$ is a vector that contains the equation prediction errors or disturbance terms. The LISREL measurement models are written in the following set of matrix equations:

$$
Y=\Lambda_{y} \eta+\varepsilon
$$

for the latent dependent variables and:

$$
X=\Lambda_{x} \xi+\sigma
$$

for the latent independent variables. The observed variables are denoted by the vector $Y(p \times 1)$ for the measures of the latent dependent variables $\eta(m \times 1)$, and by the vector $X(q \times 1)$ for the measures of the latent independent variables $\xi(n \times 1)$. The relationships between the observed variables and latent variables are denoted by the $(p \times m)$ matrix $\Lambda_{y}$ for $Y_{s}$; and by the $q \times n$ matrix $\Lambda_{x}$ for $X_{s}$. Finally, the measurement errors for $Y_{s}$ are denoted by $p \times 1$ vector $\varepsilon$ and for $X_{s}$ by the $q \times 1$ vector $\sigma$. 
Reliability of questionnaire expressed by Cronbach's alpha $(\alpha)$ to judge the consistency of items. Questionnaire validity was created by item content validity. Subject information showed the distribution of subject's demography. Correlations expressed by Pearson-product moment correlation coefficient to discuss the relevant relationships among the service quality, brand image, customer satisfaction, and customer loyalty.

\section{Results}

\section{Reliability and Validity}

The reliability coefficients of internal consistency of four sub-questionnaires, service quality, brand image, customer satisfaction, and customer loyalty, were $0.877,0.813,0.830$, and 0.845 , respectively. All reliabilities were higher than 0.70 . More specifically, the reliability of sub-questionnaires was seemly excellent (Nunnally, 1967). Validity of questionnaire would adopt the content validity to present the item validity. Researchers used Two-way Detailed Catalogue Table (TDCT) method to construct questionnaire content validity. The processes of TDCT method were firstly defined the meaning of the variables of service quality, brand image, customer satisfaction, and customer loyalty, and then listed the corresponding items of questionnaires. Finally, checked and refined the definitions and items by three experts to finish the reasonable content validity.

\section{Subject Information}

Subject information was described by the subject's demography and basic descriptive statistics. These contents comprised of gender, age, academic credentials, average income, and leisure expenses. The total number of samples was 300 (144 male and 156 female). Age levels between 25-34 years accounted for the most, constituted 32.7\%; 35-44 years accounted for 24.0\%. Distribution of age levels was to be found lie between 18-65 years. Distribution of subject's academic credentials; undergraduate level accounts for the most, constituting $40.3 \%$; junior college level accounted for 20.2\%. Average income; 40,000-59,999 NT dollars per month showed the most, constituting $31.7 \%$; 20,000-39,999 NT dollars was second, constituting $28.7 \%$. leisure expenses, below 5,000 NT dollars per year was the most, constituting 32.3\%; 5,001-10,000 NT dollars per year was second, constituting $28.0 \%$. As the subject's demography shown, the distribution of samples based on gender, age, and academic credentials were seemingly balanced. It was comprised of various levels of population; the sample seemly satisfied statistical demands. It was suitable for use on the linear structural relation model testing.

\section{Correlations}

Correlation analysis adopted the Pearson's correlation coefficient to illustrate the relevant relationships among the four variables - service quality, brand image, customer satisfaction, and customer loyalty. All correlation coefficients were shown in Table 1 , which showed the correction coefficient of service quality and customer loyalty was $0.653(p<0.01)$, depicting the two factors to be positively related. This result entirely conformed to hypothesis (H1). The correlation coefficient of brand image and customer loyalty was 0.642 ( $p<$ $0.01)$, identifying the two factors as positively related. This entirely conformed to hypothesis (H2). The correlation coefficient of customer satisfaction and customer loyalty was $0.755(p<0.01)$, showing the two factors to be positively related. This entirely conformed to hypothesis H3. In conclusion, the three hypotheses- $\mathrm{H} 1-\mathrm{H} 3$, that the article proposed, have been proved.

\section{LISREL Model Testing}

LISREL analysis inquired about the reciprocated and complementary influence effect of four variables, service quality, brand image, customer satisfaction, and customer loyalty (Jöreskog \& Sörbom, 1993a). Concerns 
about multifactor causality relationships were suitable for utilizing the LISREL instrument (Jöreskog \& Sörbom, 1993b). LISREL outputs were described as below, including the overall model and internal model fitting, as well as analysis of the discussion of test result. In addition, discussion of the actual example was presented.

Table 1

Correlation Coefficient of Service Quality, Brand Image, Customer Satisfaction and Customer Loyalty

\begin{tabular}{lllll}
\hline & Service quality & Brand image & Customer satisfaction & Customer loyalty \\
\hline Service quality & - & $0.719\left(^{* *}\right)$ & $0.743\left({ }^{* *}\right)$ & $0.653\left(^{* *}\right)$ \\
Brand image & - & $0.725\left(^{* *}\right)$ & $0.642\left(\left(^{* *}\right)\right.$ \\
Customer satisfaction & & - & $0.755\left(^{* *}\right)$ \\
Customer loyalty & & & - \\
\hline
\end{tabular}

Note. ${ }^{* *}$ Significant at the $1 \%$ level.

\section{The Overall Model-Fitting Test}

The overall model-fitting test adopted the maximum likelihood method to carry out the LISREL program (Jöreskog \& Sörbom, 1998). The output of the overall model-fitting diagram was shown in Figure 3. As shown in the outputs, the fit indices of this model, chi-squared $\left(\chi^{2}\right)$ was 128.639 with 95 degrees of freedom; goodness-of-fit index (GFI) was 0.952; normalized fit index (NFI) was 0.986, comparative fit index (CFI) was 0.996, adjusted goodness-of-fit index (AGFI) was 0.931, and root mean square error of approximation (RMSEA) was 0.0301. Hence, this model fits the data very well (Jöreskog \& Sörbom, 1993a; Hair, Black, Babin, \& Anderson, 2010). In conclusion, the fit estimates were all ranged within a reasonable scope (Schumacker \& Lomax, 1996).

\section{The Internal Structure Model-Fitting Test}

The output of the internal structure model-fitting test could be expressed by estimates and $t$-values (see Table 2). The parameter of Gamma $(\gamma)$ and Beta $(\beta)$ expressed the relationship between latent variable and latent variable. The parameter of Lambda $\left(\lambda_{x}\right)$ and Lambda $\left(\lambda_{y}\right)$ expressed the relationships between latent variable and its observed variables respectively.

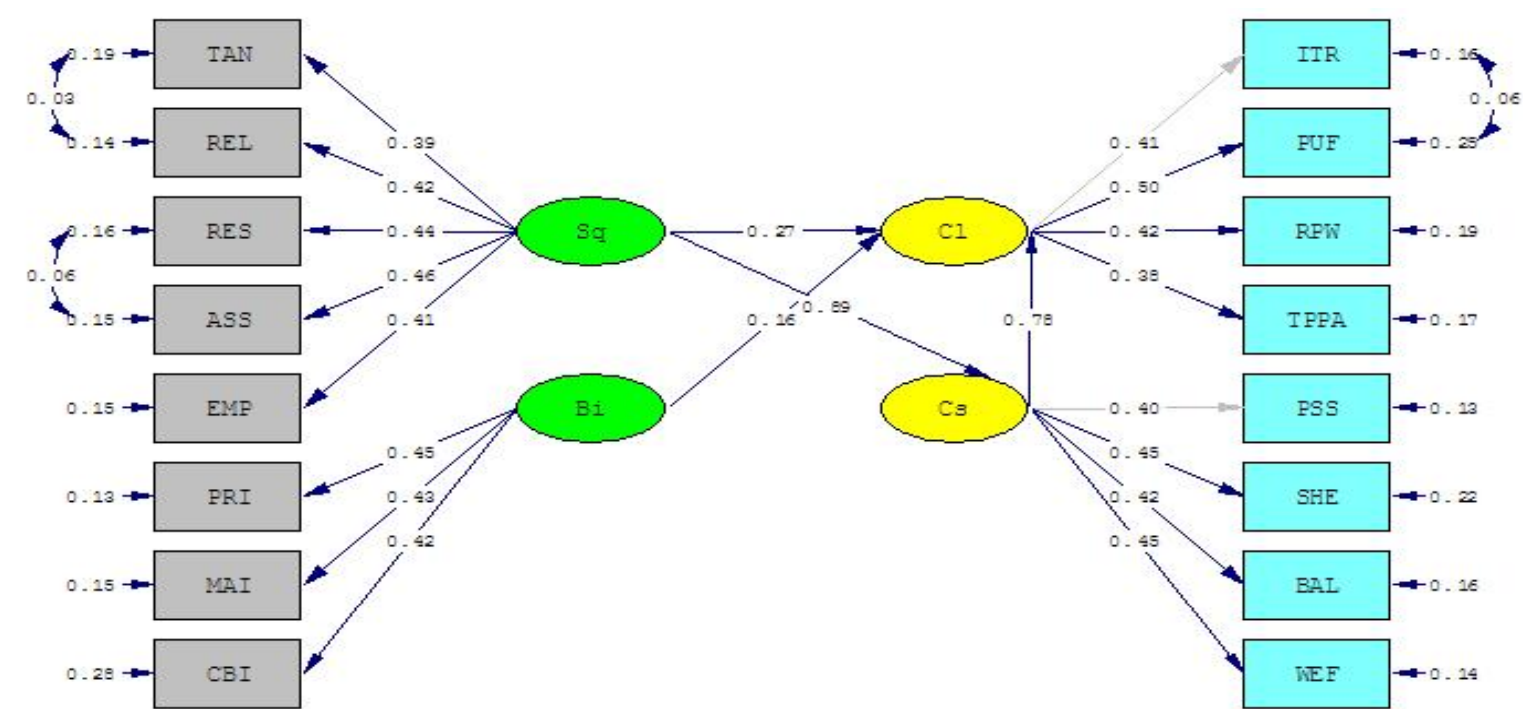

Figure 3. Diagram of LISREL model testing output. 
As Table 2 shows, all of the parameters' estimates and $t$-values were all greater than 2.58 and $p<0.01$, Hence, all these variables displayed extremely high expectations. The internal structure model fits the data very well. As the output shown, all parameter coefficients of completely standardized solutions very nearly fitted the indices. Otherwise, all the error covariances were positive, the $t$-value of error covariances was significant, and all the estimated parameters were large than $2.58(p<0.01)$. Thereby, indicating the internal structure model fits the data very well.

Table 2

Parameter Estimates of LISREL Model

\begin{tabular}{llr}
\hline LISREL parameters & Estimate & $t$-value \\
\hline Gamma $\left(\gamma_{21}\right)(\mathrm{Sq} \rightarrow \mathrm{Cs})$ & 0.89 & 12.72 \\
Gamma $\left(\gamma_{11}\right)(\mathrm{Sq} \rightarrow \mathrm{Cl})$ & 0.27 & 4.71 \\
Gamma $\left(\gamma_{12}\right)(\mathrm{Bi} \rightarrow \mathrm{Cl})$ & 0.16 & 4.12 \\
Beta $\left(\beta_{12}\right)(\mathrm{Cs} \rightarrow \mathrm{Cl})$ & 0.78 & 5.20 \\
Lambda $\left(\lambda_{x 11}\right)(\mathrm{Sq} \rightarrow \mathrm{TAN})$ & 0.39 & 12.49 \\
Lambda $\left(\lambda_{x 21}\right)(\mathrm{Sq} \rightarrow \mathrm{REL})$ & 0.42 & 14.29 \\
Lambda $\left(\lambda_{x 31}\right)(\mathrm{Sq} \rightarrow \mathrm{RES})$ & 0.44 & 14.25 \\
Lambda $\left(\lambda_{x 41}\right)(\mathrm{Sq} \rightarrow \mathrm{ASS})$ & 0.46 & 14.79 \\
Lambda $\left(\lambda_{x 51}\right)(\mathrm{Sq} \rightarrow \mathrm{EMP})$ & 0.41 & 13.88 \\
Lambda $\left(\lambda_{x 61}\right)(\mathrm{Bi} \rightarrow \mathrm{PRI})$ & 0.45 & 12.95 \\
Lambda $\left(\lambda_{x 71}\right)(\mathrm{Bi} \rightarrow \mathrm{MAI})$ & 0.43 & 12.28 \\
Lambda $\left(\lambda_{x 81}\right)(\mathrm{Bi} \rightarrow \mathrm{CBI})$ & 0.42 & 10.26 \\
Lambda $\left(\lambda_{y 11}\right)(\mathrm{Cl} \rightarrow \mathrm{ITR})$ & 0.41 & 14.47 \\
Lambda $\left(\lambda_{y 21}\right)(\mathrm{Cl} \rightarrow \mathrm{PUF})$ & 0.50 & 14.39 \\
Lambda $\left(\lambda_{y 31}\right)(\mathrm{Cl} \rightarrow \mathrm{RPW})$ & 0.42 & 11.98 \\
Lambda $\left(\lambda_{y 41}\right)(\mathrm{Cl} \rightarrow \mathrm{TPPR})$ & 0.38 & 11.72 \\
Lambda $\left(\lambda_{y 52}\right)(\mathrm{Cs} \rightarrow \mathrm{PSS})$ & 0.40 & 13.87 \\
Lambda $\left(\lambda_{y 62}\right)(\mathrm{Cs} \rightarrow \mathrm{SHE})$ & 0.45 & 11.71 \\
Lambda $\left(\lambda_{y 72}\right)(\mathrm{Cs} \rightarrow \mathrm{BAL})$ & 0.42 & 13.36 \\
Lambda $\left(\lambda_{y 82}\right)(\mathrm{Cs} \rightarrow \mathrm{WEF})$ & 0.45 & 13.31 \\
\hline
\end{tabular}

\section{Brief Summary}

The study used the LISREL method to test the proposed model. As the output shown the overall model-fitting test and the internal structure model-fitting test were all fit the data well. In summary, the hypothetical model (see Figure 1) that this study has proposed, tested by LISREL method, concluded a correct verification. This result entirely conformed to hypothesis (H4). That means the casual relationship model among service quality, brand image, customer satisfaction, and customer loyalty is like as Figure 1 shows.

Otherwise, from the internal structure model-fitting test output shown service quality adopted the tangibles, reliability, responsiveness, assurance, and empathy as observed variables being suitability; customer loyalty adopted the intent to repurchase, purchase frequency, recommendation product wish, and times of participation product activity as the observed variables being suitability; brand image adopted the product image, manufacturer image, and competitor brand image as observed variables being suitability; and customer satisfaction adopted personnel service standard, soft hardware equipment, board and lodging, and whole experience feeling as observed variables being of suitability. 


\section{Conclusions and Implications}

\section{Conclusions}

This research intended to take Taiwan domestic leisure resorts as its example; comprised of 300 subjects in the Taiwan area as samples; to discuss the leisure company's service quality, brand image, customer satisfaction and customer loyalty causality relationships. Researchers utilized LISREL method to test the hypothesized model. The verification results of LISREL testing showed that the overall model fitted the data very well (chi-square was 128.639 with 95 degrees, goodness-of-fit index (GFI $=0.950)$ ). The internal structure model-fitting test corresponded as suitable $(t>2.58, p<0.01)$. This result indicated that the theoretical structure of the framework of this research proposal had been verified by the data. Based on the above results, it was concluded that the service quality, brand image and customer satisfaction of leisure business had a direct relation with customer loyalty. These findings were in accord with the results of studies by preceding authors (Reichheld \& Sasser, 1990; Anderson \& Sullivan, 1993; Leigh, 2001; Martin, Ugur, \& Dirk, 2003; Antti \& Ugur, 2005; Chiang \& Jang, 2007; Liao, 2007; David \& Dominiek, 2008; Bindu et al., 2009; Xiang \& James, 2010; Liao \& Li, 2011).

At the same time, the study also found that the service quality could have an indirect effect on customer loyalty through customer satisfaction. Therefore, this research inferred that service quality might be the prominent factor of customer satisfaction. In a leisure service context, wherever, service quality might be proposed as antecedents of satisfaction, with their effects on loyalty mediated by satisfaction. These finding were consistent with the results of following authors (Cronin \& Taylor, 1992; Yieh, Chiao, \& Chiu, 2007; Subhash, Dennis, Mehves, Ekrem, \& Selim, 2010; Xiang \& James, 2010).

\section{Implications}

In conclusion, drawn from the results of this research, which showed the service quality in the leisure resort enterprise was an important factor influencing customer satisfaction and customer loyalty. Therefore, the results of the present study could be provided a reference for the leisure service enterprise marketing management. The majority of finding of this study implied that improving service quality was the most important issue for leisure service enterprises, especially tangibles, reliability, responsiveness, assurance, and empathy of employees to be of the highest quality, therefore the leisure service enterprise should strengthen service quality (Robert, 2001; Su, Lin, \& Chiang, 2008).

In addition, the results of this research showed that the customer satisfaction also influenced the customer loyalty in the leisure service business. If a service enterprise wants to maintain the customer loyalty, it needs to focus on satisfying the customers' expectations and actual experiences.

Implication of this study suggests that leisure service enterprise managers require offering an excellent management strategy to improving service quality and customer satisfaction. Those strategies might be the total quality control (TQM), the Plan-Do-Check-Act (PDCA) cycle. When the service quality and customer satisfaction were aggressively improved, the leisure service business would be able to maintain their current customers and loyalty.

\section{References}

Aaker, D. A., \& Jacobson, R. (1994). The financial information content of perceive quality. Journal of Marketing Research, 31(2), 191-201. 
Anderson, W. E., \& Sullivan, W. M. (1993). The antecedents and consequences of customer satisfaction for firms. Marketing Science, 28(1), 125-143.

Antti, H., \& Ugur, Y. (2005). The effect of customer satisfaction with leisure services on behavioral intentions: A study of visitors to Santa Park in Lapland. Services Marketing Quarterly, 26(3), 1-12.

Biel, A. L. (1992). How brand image drives brand equity. Journal of Advertising Research, 32(6), 6-12.

Bindu, N., Chandrasekharan, R., Prakash, S. L., \& Ram, G. (2009). Dimensions of service quality in tourism-An Indian perspective. Total Quality Management \& Business Excellence, 20(1), 61-89.

Chang, C. H., \& Yuan, S. J. (2002). Service-oriented industrial management. Taipei: Yang-Chih Book Co. Ltd..

Changhong, B., Fujun, L., Ye, C., \& Joe, H. (2008). Conceptualizing the perceived service quality of public utility services: A multi-level, multi-dimensional model. Total Quality Management and Business Excellence, 19(10), 1055-1070.

Chiang, C. F., \& Jang, S. S. C. (2007). The effects of perceived price and brand image on value and purchase intention: Leisure travelers' attitudes toward online hotel booking. Journal of Hospitality Marketing and Management, 15(3), 49-69.

Cronin, J. J., \& Taylor, S. A. (1992). Measuring service quality: A reexamination and extension. Journal of Marketing, 56(3), 55-68.

David, J. K., \& Dominiek, C. (2008). Retirement village resident satisfaction in Australia: A qualitative enquiry. Journal of Housing for the Elderly, 22(4), 311-334.

Day, R. L. (1977). Extending the concept of consumer satisfaction. Advances in Consumer Research, 4(1), 149-154.

Dermanov, V., \& Eklöf, J. (2001). Using aggregate customer satisfaction index: Challenges and problems of comparison with special reference to Russia. Total Quality Management and Business Excellence, 12(7-8), 1054-1063.

Dwyer, F. R., Schurr, P. H., \& Oh, S. (1987). Developing buyer-seller relationships. Journal of Marketing, 51(2), 11-27.

Etzel, M. J., Walker, B. J., \& Stanton, W. J. (2001). Marketing management (12th ed.). McGraw-Hill.

Gary, H., James, A., Gary, C., \& Ian, M. (2001). Measuring customer service quality in sports and leisure centres. Managing Leisure, 1(2), 77-89.

George, C., Eleni, G., Mario, G., \& Panagiotis, A. (2004). Recreational services in resort hotels: Customer satisfaction aspects. Journal of Sport and Tourism, 9(2), 117-126.

Grewal, D., Krishnan, R., Julie, B., \& Norm, B. (1998). The effect of store name, brand name, and price discounts on consumers' evaluations and purchase intentions. Journal of Retailing, 74, 331-352.

Griffin, J. (1996). Customer loyalty. Simon and Schuster Inc..

Grönroos, C. (1998). Marketing services: The case of a missing product. Journal of Business and Industrial Marketing, 13(4/5), 322-338.

Grönroos, C. (2003). Service management and marketing: A customer relationship management approach (2nd ed.). John Wiley and Sons.

Hair, J. F., Black, W. C., Babin, B. J., \& Anderson, R. E. (2010). Multivariate data analysis (7th ed.). N.J.: Pearson Prentice Hall.

Jennifer, K. L. C., \& Tom, B. (2007). Researching consumer satisfaction: An extension of Herzberg's motivator and hygiene factor theory. Journal of Travel and Tourism Marketing, 23(1), 71-83.

Jones, T. O., \& Sasser, W. E. Jr. (1995). Why satisfied customer defect. Harvard Business Review, 73(6), 88-99.

Jöreskog, K., \& Sörbom, D. (1993a). LISREL 8: Structural Equation Modeling with the SIMPLIS Command Language. Chicago, IL 60615, Scientific Software International.

Jöreskog, K., \& Sörbom, D. (1993b). LISREL 8 user's reference guide. Chicago: Scientific Software International.

Jöreskog, K., \& Sörbom, D. (1998). LISREL 8.20 software. Chicago, I.L. 60646-1704, Scientific Software International, 7383 N.

Kenneth, E. C., Judith, A. G., \& David, L. K. (1995). An exploratory study into the purchase decision process used by leisure travelers in hotel selection. Journal of Hospitality Marketing and Management, 2(4), 53-72.

Klaus, W., \& Christine, M. (2004). The tourism and leisure industry: Shaping the future. Haworth Press.

Kotler, P., \& Keller, K. (2006). Marketing management: Customer value, customer satisfaction and customer loyalty (12th ed.). Prentice-Hall.

Kuo, Y. F. (2004). Integrating Kano's model into web-community service quality. Total Quality Management and Business Excellence, 15(7), 925-939.

Lee, Jo., Lee, Ja., \& Feick, L. (2001). The impact of switching costs on the customer satisfaction-loyalty link: Mobile phone service in France. Journal of Services Marketing, 15(1), 35-48.

Leigh, R. (2001). Is quality management appropriate for public leisure services? Managing Leisure, 7(1), 33-40. 
Liao, K. H. (2007, December). The study of causal relationships among telecommunication service quality, customer satisfaction, and loyalty-Samples of customers in the Taiwan area. Paper presented at the 8th Asia Pacific Industrial Engineering and Management System and 2007 Chinese Institute of Industrial Engineers Conference, Kaohsiung, Taiwan.

Liao, K. H., \& Li, Y. C. (2011, September). The effects of service quality and customer satisfaction on customer loyalty in steel company services. Paper presented at IEEE The 18th International Conference on Industrial Engineering and Engineering Management, held on September 3-5, 2011 in Changchun, China.

Lutz, R. (1986). Quality is as quality does: An attitudinal perspective on consumer quality judgments. Presentation to The Marketing Science Institute Trustees' Meeting, Cambridge, M.A..

Mackenzie, S. B., \& Spreng, R. A. (1992). How does motivation moderate the impact of central and peripheral processing on brand attitudes and intentions? Journal of Consumer Research, 18(4), 519-529.

Manfred, B., \& Grund, M. A. (2000). Theory, development and implementation of national customer satisfaction indices: The Swiss Index of Customer Satisfaction (SWICS). Total Quality Management and Business Excellence, 11(7), 1017-1028.

Martin, B., Ugur, Y., \& Dirk, F. (2003). Emotional and cognitive antecedents of customer satisfaction in leisure services: The case of the rostock zoo. Journal of Hospitality Marketing and Management, 10(3), 173-184.

Matthew, C. H., \& Christine, T. E. (2000). From customer satisfaction to profitability. Journal of Strategic Marketing, 8(4), 313-326.

Monica, Z. L. (2009). Leisure and tourism in the Changing China. World Leisure Journal, 51(4), 252-260.

Nunnally, J. (1967). Psychometric theory. New York: McGraw-Hill.

Parasuraman A., Zeithaml V. A., \& Berry, L. L. (1988). SERVQUAL: A multiple-item scale for measuring consumer perceptions of service quality. Journal of Retailing, 64(1), 12-40.

Parasuraman, A., Zeithaml V. A., \& Berry, L. L. (1996). The behavioral consequences of service quality. Journal of Marketing, $60(2), 31-46$.

Parasuraman, A., Zeithaml, V. A., \& Berry, L. L. (1994). Alternative scales for measuring service quality: A comparative assessment based on psychometric and diagnostic criteria. Journal of Retailing, 70(3), 201-230.

Parsuraman, A., Zeithaml, V. A., \& Berry, L. L. (1985). A conceptual model of service quality and its implications for future research. Journal of Marketing, 49(2), 44-50.

Reichheld, F. F. (1996). The loyalty effect. The hidden forces behind growth, profits, and lasting value. Boston, M.A.: Harvard Business School Press.

Reichheld, F. F., \& Sasser, E. W. (1990). Zero defections: Quality comes to services. Harvard Business Review, 68(5), $105-111$.

Robert, L. (2001). Untangling the tangibles: Physical evidence and customer satisfaction in local authority leisure centres. Managing Leisure, 5(1), 1-16.

Saravanan, R., \& Rao, K. S. (2007). Measurement of service quality from the customer's perspective-An empirical study. Total Quality Management and Business Excellence, 18(3), 435-449.

Schumacker, R. E., \& Lomax, R. G. (1996). A beginner's guide to structural equation modeling. Lawrence Erlbaum Associates, Publishers Mahwah, New Jersey.

Singh, J. (1991). Understanding the structure of consumers satisfaction evaluation of service delivery. Journal of the Academy of Marketing Science, 19(3), 223-234.

Su, C. T., Lin, C. S., \& Chiang, T. L. (2008). Systematic improvement in service quality through TRIZ methodology: An exploratory study. Total Quality Management and Business Excellence, 19(3), 223-243.

Subhash, L., Dennis, M., Mehves, T., Ekrem, T., \& Selim, Z. (2010). An evaluation of SERVQUAL and patient loyalty in an emerging country context. Total Quality Management and Business Excellence, 21(8), 813-827.

Sundar, G. B., Kapil, R. T., \& Andre, B. (2011). The impact of brand quality on shareholder wealth. Journal of Marketing, 75(5), 88-104.

Tim, B., Thomas, L. B., \& Trevor, S. (1993). Quality products, quality service: Factors leading to entrepreneurial success in the sport and leisure industry. Leisure Studies, 12(2), 93-106.

Xiang, L., \& James, F. P. (2010). Towards an integrative model of loyalty formation: The role of quality and value. Leisure Sciences: An Interdisciplinary Journal, 32(3), 201-221.

Yieh, K., Chiao, Y. C., \& Chiu, Y. K. (2007). Understanding the antecedents to customer loyalty by applying structural equation modeling. Total Quality Management and Business Excellence, 18(3), 267-284. 